\title{
Poeira do Tempo - memória coletiva e figurinos do imaginário gaúcho. Porto Alegre: Programa de Pós-graduação em Antropologia Social/UFRGS, 2014.
}

\section{(Documentário etnográfico).}

\section{Felipe da Silva Rodrigues ${ }^{1}$}

Com a fugacidade do tempo a narrativa perdura na personificação de seus narradores que fazem parte e constroem o imaginário presente no documentário etnográfico a Poeira do Tempo - memória coletiva e figurinos do imaginário gaúcho, uma realização do Banco de Imagens e Efeitos Visuais (BIEV) - Lab. de Antropologia Social - PPGAS -UFRGS, que reúne registros de narrativas biográficas, de homens e mulheres, durante sete anos, em viagens pelo Estado do Rio Grande do Sul e na região metropolitana de Porto Alegre. Personagens que são verdadeiros guardiões da memória coletiva da sociedade gaúcha e seus mitos de fundação. Entre histórias e imagens o documentário reconstrói a paisagem do Rio Grande do Sul, quer seja através da memória dos narradores ou da evocação dessas narrativas na imaginação do espectador do documentário. Traz à tona o fantástico pela partilha dos mitos e das lendas presentes nos "causos" e histórias contadas.

Os personagens, interlocutores do documentário etnográfico, nos apresentam narrativas que refazem as suas trajetórias biográficas suscitando um passado que se cristaliza no presente onde se dá a dialética, assimilação e acomodação, do tempo. Assim, através do reordenamento dos instantes descontínuos, temos a duração e a (re)construção das imagens dessas histórias, bem como a sua vibração no tempo.

A narrativa baseada nas memórias dos narradores tem na oralidade a sua forma de sustentação, descontínuas e ritmadas, faladas com todo o adagiário popular do pampa. Estes "causos" do passado, tempo vivido, nos prendem pela sua sonoridade e certa estranheza, seja pelo linguajar gauchesco e interiorano, seja pela temática das histórias. E assim podemos acessar as imagens presentes nessas narrativas e fabular junto com os narradores esta imaginação fantástica.

No documentário etnográfico também está presente o tom de denúncia dos descendentes e remanescentes dos povos originários que compartilham de sua sabedoria, ora sobre os artesanatos, meio de sustendo desses indígenas que esperam a demarcação

\footnotetext{
${ }^{1}$ Universidade Federal do Rio Grande do Sul, Brasil.
} 
de suas terras, ora falando da medicina não tradicional, chás e ervas que podem curar males modernos, doenças que não são da carne. Conhecimento, herdado de seus antepassados e transmitido de geração em geração através da oralidade, que é repassado ao espectador, o qual passa a fazer parte dessa rede de conhecimento sobre cura através de ervas medicinais.

A cura surge também pela fé nas preces das benzedeiras. Elas narram histórias passadas de salvação de doentes através da reza, repetindo as orações que as fizeram curar os enfermos. Tratam de doenças como a depressão e outros males e afastando-as dos pacientes, pela invocação de santos e promessas. A expurgação dos males vem pela palavra e pela fé das rezadeiras, da fé pacientes na sua cura e, agora, pela fé daqueles que ouvem esses relatos e passam a crer também.

Já as lendas e os mitos apresentam-nos o fantástico, as histórias contadas com elementos sobrenaturais trazem a incerteza, a desconfiança, o medo e o desconhecido. No creo en las brujas pero que las hay las hay, e agora as bruxas existem e passam a fazer parte da imaginação dos espectadores, assim como o lobisomem, pois através dessas narrativas fantásticas acessamos a memória coletiva, da qual os personagens do documentário etnográfico são os guardiões e esses seres fantásticos fazem parte. Assim, começamos a partilhar junto com os narradores essas imagens de lendas e mitos da cultura presente no Estado do Rio Grande do Sul.

As histórias de guardados e de tesouros escondidos aparecem-nos como uma metáfora da própria memória dos narradores. Memória que é muito rica, mas que para ser acessada é preciso seguir as pistas e se embrenhar na busca desses devaneios, do tempo, na recriação de um "caminho" que nos levará à memória coletiva presente nesses relatos, dos quais os narradores são os guias ao reconstruírem essas histórias na riqueza de seus relatos.

A busca por acessar essa memória é o desafio do documentário etnográfico, Poeira do Tempo - memória coletiva e figurinos do imaginário gaúcho, produzido sob a égide da etnografia da duração (Eckert \& Rocha, 2013), que assim como a memória das personagens também dura no tempo e vibra na imaginação daqueles que o assistem. Mesclando imagens de acervo, paisagens do pampa gaúcho e as narrativas das personagens, o documentário em sua edição trama os fios do tempo e trás à tona toda a 
recordação dos mitos e lendas, resistindo à poeira do tempo e perdurando presentes na memória coletiva no imaginário do folclore rio-grandense.

\section{Ficha Técnica:}

Realização: Banco de Imagens e Efeitos Visuais (BIEV) - Lab de Antropologia Social PPGAS - UFRGS

Duração: 55 Min

Formato: DV-NTSC

Direção: Ana Luiza Carvalho da Rocha

Coordenação: Ana Luiza Carvalho da Rocha, Cornelia Eckert

Roteiro: Ana Luiza Carvalho da Rocha e Pedro da Rocha Paim

Pesquisador de campo: Olavo Ramalho Marques

Imagens: Rafael Devos, Peri Carvalho, Jean Arlaud, Ana Luiza Carvalho da Rocha, Pedro da Rocha Paim

Imagens sonoras: Viviane Vedana

Edição: Pedro da Rocha Paim, Patrick Barcellos, Ana Paula E. Parodi, Marize Schons,

Rodrigo Ramalho

Finalização: Pedro da Rocha Paim.

\section{Referências}

ROCHA, Ana. Luiza C.; ECKERT, Cornelia ; ROCHA, L. A. . Poeiras do Tempo no sul do Brasil: percursos etnográficos. Brasilia: Editora da Associação Brasileira de Antropologia, 2015 (Etnografia em hipermidia). Disponível em: < https://www.ufrgs.br/biev/?xylus-portfolio=poeiras-do-tempo>.

ECKERT, Cornelia e ROCHA, Ana Luiza C. Etnografia da duração - antropologia das memórias coletivas em coleções etnográficas. 1a. ed. Porto Alegre: Marcavisual, 2013. v. $1000.256 \mathrm{p}$. 